\title{
Design of Broadband Microstrip Patch Antenna for WLAN/WiMAX Applications
}

\author{
Dr. Yessar E. Mohammed Ali \\ a.yessar@yahoo.com
}

Dept. Electrical Engineering

College of Engineering/University of Mosul/Iraq
Khalid A. Sultan Jasim

khalidsultan3041@yahoo.com

\section{Abstract}

In this paper design of a broadband printed microstrip patch antenna suitable for wireless communication (WLAN/WiMAX) applications is presented. The antenna occupies small size of $50 \times 40 \times 1.6 \mathrm{~mm}^{3}$. Parallel slots and corner notch are employed in a rectangular patch to achieve broadband characteristics. Two parasitic elements are printed on the bottom surface of the substrate to give good performance. The proposed antenna has return losses of $-32 \mathrm{~dB}$ and $-30.8 \mathrm{~dB}$ at $2.4 \mathrm{GHz}$ and $3.5 \mathrm{GHz}$ respectively. The bandwidth is $1.768 \mathrm{GHz}$ (from $1.985 \mathrm{GHz}-3.753 \mathrm{GHz}$ ) at $\mathrm{S11}<-10 \mathrm{~dB}$. The maximum gain is $2.8 \mathrm{dBi}$ for $2.4 \mathrm{GHz}$ and $3.3 \mathrm{dBi}$ for $3.5 \mathrm{GHz}$. The simulated results are obtained using the software computer simulation technology CST. The designed antenna is printed at a low cost on FR-4 substrate and simple feeding using microstrip line feed.

Keywords: dual-band, microstrip antenna, WiMAX, WLAN, parasitic elements.

\section{تصميم هوائي شريحة رقيقة ذو حزمة واسعة النطاق لتطبيقات WLAN/WiMAX}

$$
\begin{aligned}
& \text { خالا علي سلطان جاسم } \\
& \text { د. يسار عز الدين محمد علي } \\
& \text { قسم الهندسة الكهربائية } \\
& \text { كلية الهنسة/ جامعة الموصل/ العراق }
\end{aligned}
$$

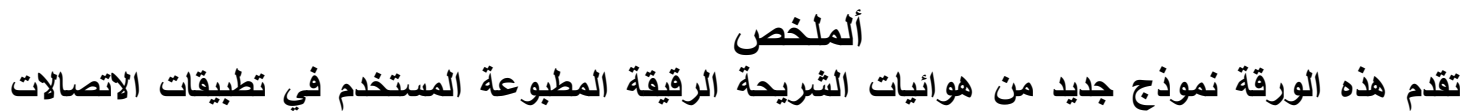

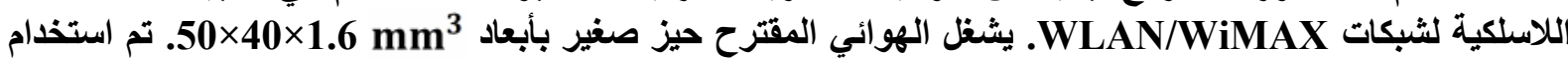

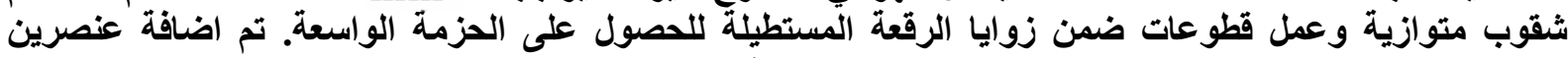

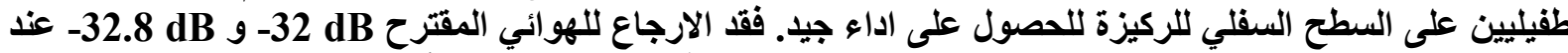

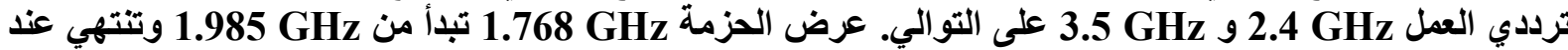

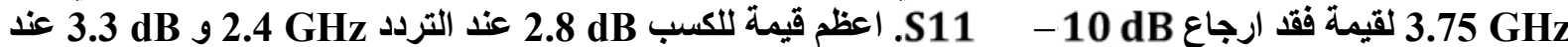

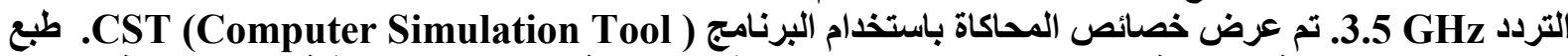
الهو ائي المصم بتكلفة منخفضة على ركيزة نوع FR-4 وتم تغذيته بسهولة باستخدام خط التغذية نوع الثريحة. 


\section{1- INTRODUCTION:}

Rapid progress in wireless communication services has led to an enormous challenge in antenna design. Patch antennas for dual and multi frequency bands operation has increasingly become common because of, many advantages such as low profile, light weight, reduced volume and compatibility with microwave integrated circuits (MIC) and monolithic microwave integrated circuit (MMIC). WLAN is one of the most important applications of the wireless communication technology that takes advantage of license free frequency bands industrial, scientific and medical (ISM), due to high speed connectivity between PCs, laptops, cell phones and other equipment in environments. Currently WiMAX technology with different standards is going to occupy the market. Wireless data services have evolved and continue to grow using various technologies, such as $2 \mathrm{G} / 3 \mathrm{G}$. The impact of such diverse technologies is on the use of frequency band in different technologies will need to occupy different frequency allocations, such as WLAN/WiMAX, it likely to be prominent candidate to serve for wireless data in near future. Therefore, there is a need to develop a dual band antenna for both WLAN and WiMAX applications [1].

Several papers on broadband antennas for IEEE standards have been reported. In [2] a printed microstrip-line-fed broadband rhombus slot antenna is investigated. Offset microstrip feed line and the corner truncated protruded ground plane are used to enhanced the bandwidth. In [3] a novel broadband microstrip antenna for various wireless application is investigated and presented. In [4] a rectangular microstrip patch antenna with (W) slotted patch is presented. Frequency band of the proposed antenna is in between 1.45-3.25 GHz and the fractional bandwidth $76.59 \%$. In [5] a probe fed bow-tie shaped antenna is designed. Frequency range of the proposed antenna $(1.91 \mathrm{GHz}-3.236 \mathrm{GHz})$. This antenna can produce two resonant frequencies $2.209 \mathrm{GHz}$ and $2.904 \mathrm{GHz}$. In [6] The conventional rectangular microstrip antenna has been first designed as a reference antenna, then two proposed prototypes of broadband microstrip antennas (E-shape and four-edges gap-coupled planar multi resonator) were designed.

WLAN and WiMAX standards specify many bandwidth and many operating frequencies around the world, so to satisfy this applications a multi band antennas are required for the future communication terminal. Modern antennas must meet the requirement of multi-band or wideband to sufficiently cover the possible operating bands. The antenna must also be small enough to be placed inside the minimizing wireless communication systems [7].

In this paper, a simple broadband rhombic-patch printed microstrip antenna is presented. The antenna operates a bandwidth of $1.7686 \mathrm{GHz}$ at $\mathrm{S} 11<-10 \mathrm{~dB}$ with two resonant frequencies of $2.4 \mathrm{GHz}$ and $3.5 \mathrm{GHz}$. The proposed antenna can easily be fed with a $50 \Omega$ microstrip line. More characteristics of the proposed antenna and analysis results were presented below by using the software computer simulation technology (CST).

\section{2- ANTENNA STRUCTURE AND DESIGN}

Three essential factors (operating frequency, dielectric substrate and substrate height) represent the fundamental base in a printed microstrip patch antenna design. Then a five 
mathematical relations are used to find the dimensions of the conventional rectangular microstrip patch antenna.

- Operating frequency $(\boldsymbol{f})$ : The operating frequency of the designed antenna must be suitable for the concerned application.

- Dielectric constant of the substrate $\left(\varepsilon_{r}\right)$ : The substrate material selected for the design is epoxy which has a dielectric constant of $\varepsilon_{r}=4.3$.

- Height of dielectric substrate $(\boldsymbol{h})$ : The height of the dielectric substrate is $1.6 \mathrm{~mm}$. Hence, the microstrip patch antenna is not bulky to be used in hand-held unit.

The five mathematical relations that are used to design the conventional rectangular patch antenna are: [8][9]

Width calculation: $\quad W=\frac{c}{2 \times \sqrt{\frac{\varepsilon_{r}+1}{2}}}$

Effective dielectric constant calculation: $\quad \varepsilon_{\text {reff }}=\frac{\varepsilon_{r}+1}{2}+\frac{\varepsilon_{r}-1}{2}\left[1+\frac{h}{w}\right]^{-1 / 2}$

Effective length calculation: $\quad L_{e f f}=\frac{c}{2 \times f \sqrt{\varepsilon_{\text {reff }}}}$

Length extension calculation: $\quad \Delta L=0.412 \times h \times \frac{\left(\varepsilon_{\text {reff }}+0.3\right) \times\left(\frac{W}{h}+0.264\right)}{\left(\varepsilon_{\text {reff }}-0.258\right)+\left(\frac{W}{h}+0.8\right)}$

Actual length calculation: $\quad L=L_{\text {eff }}-2 \times \Delta L$

Figure 1. shows the conventional shape of the designed antenna. Table. 1 shows the dimensions of the conventional design measured in $\mathrm{mm}$.

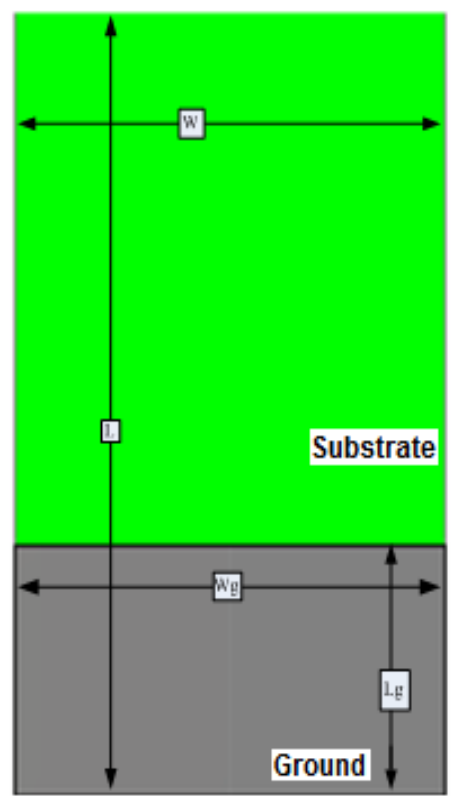

Ground plane

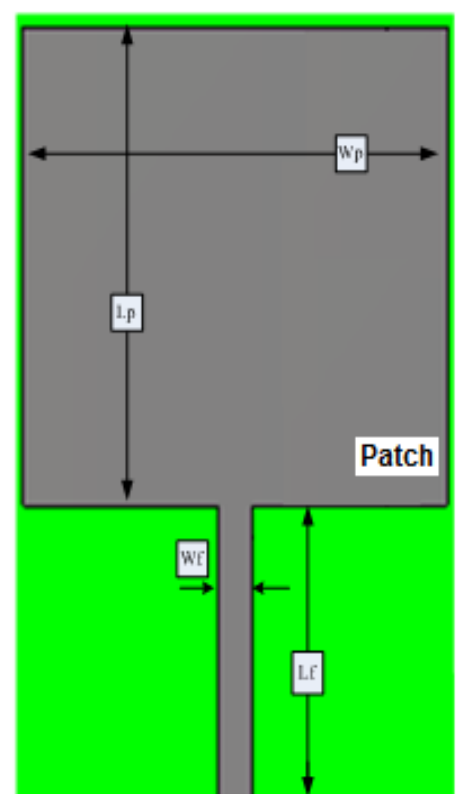

Patch plane

Fig. (1) the conventional proposed antenna 
Table. 1 dimensions of the antenna

\begin{tabular}{|c|c|c|c|c|c|c|c|}
\hline \multicolumn{7}{|c|}{ Dimensions measured in mm } \\
\hline Wg & Lg & Wf & Lf & Wp & Lp & W & L \\
\hline 40 & 16 & 3 & 19 & 38.4 & 29.7 & 38.4 & 50 \\
\hline
\end{tabular}

Some necessary amendments like cuts, slots, corner notch on the patch and using of parasitic elements on the ground plane are conducted on the conventional design. Figure 2. shows the final shape of the design. Table. 2 shows the dimensions of the final designed antenna measured in $\mathrm{mm}$. The conventional and the final form and the results of the designed antenna are shown below using "CST" program.

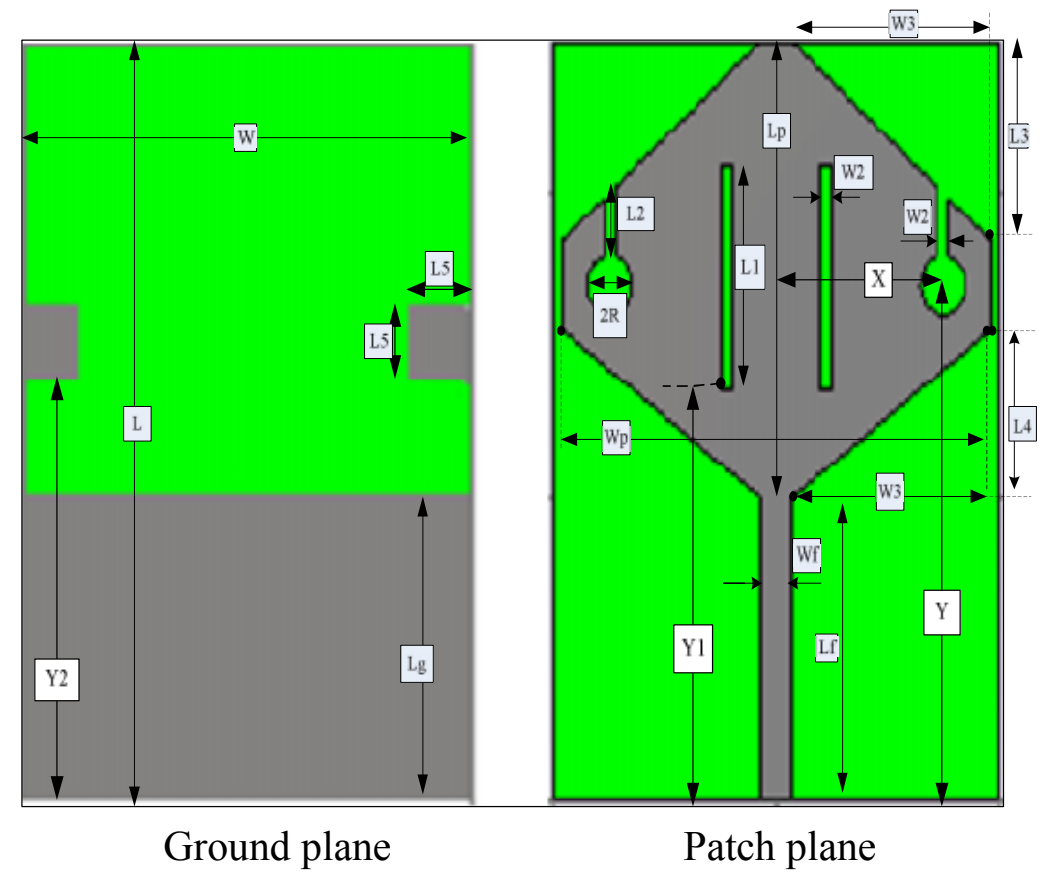

Fig. (2) the final proposed antenna

Table. 2 dimensions of the final form designed

\begin{tabular}{|c|c|c|c|c|c|c|c|c|c|}
\hline \multicolumn{10}{|c|}{ Dimensions measured in mm } \\
\hline L & W & Lp & Wp & Lf & Wf & L1 & L2 & Y1 & Y2 \\
\hline 50 & 40 & 30 & 38.4 & 20 & 3 & 5 & 6 & 27 & 28 \\
\hline L3 & W2 & L4 & W4 & Lg & W1 & 2R & Y & X & L5 \\
\hline 13 & 1 & 11 & 17.3 & 20 & 1 & 2 & 34 & 15 & 4 \\
\hline
\end{tabular}




\section{3- RESULTS AND DISCOSSION}

Figure (3) shows the return loss of the designed antenna. The return loss is $-32 \mathrm{~dB}$ at $2.4 \mathrm{GHz}$ and $-30.8 \mathrm{~dB}$ at $3.5 \mathrm{GHz}$. Also we can see that the antenna operates in a wideband of $1.768 \mathrm{GHz}(1.985-3.753 \mathrm{GHz})$ at $\mathrm{S} 11<-10 \mathrm{~dB}$.

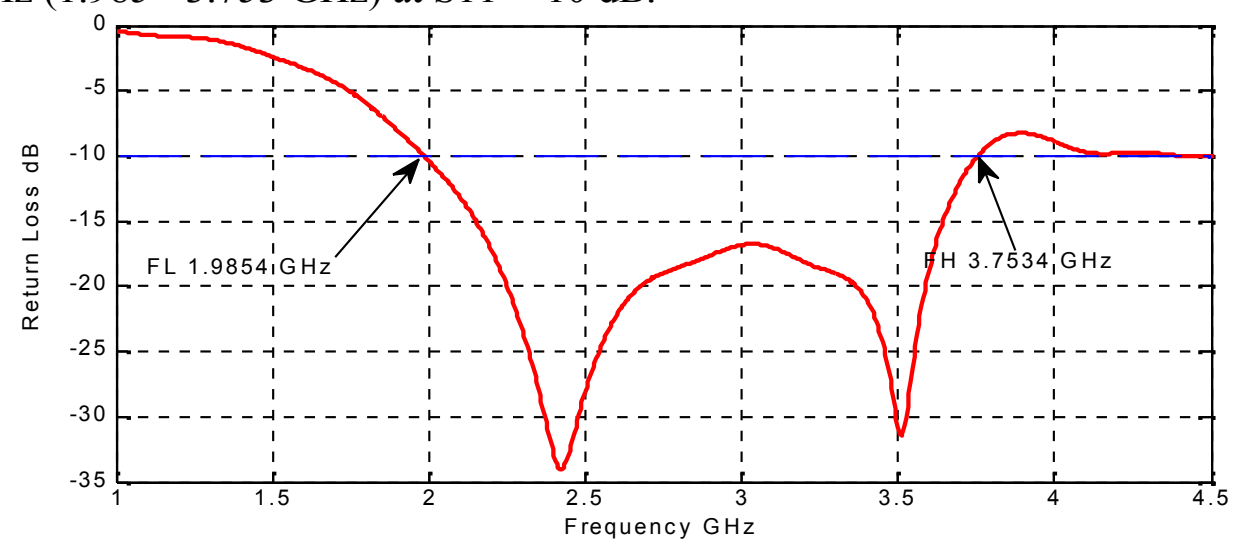

Fig. (3) Return loss

Fractional bandwidth (FBW): Is the ratio of the difference of the upper and lower frequencies of acceptable operation to the center frequency of that band multiplied by 100 [10].

$$
\begin{aligned}
\mathrm{BW} & =3.753473 \mathrm{GHz}-1.985400 \mathrm{GHz}=1.768073 \mathrm{GHz} \\
\mathrm{FBW}_{1} & =\frac{3.753473 \mathrm{GHz}-1.985400 \mathrm{GHz}}{2.4 \mathrm{GHz}} \times 100 \%=73.67 \% \\
\mathrm{FBW}_{2} & =\frac{3.753473 \mathrm{GHz}-1.985400 \mathrm{GHz}}{3.5 \mathrm{GHz}} \times 100 \%=50.51 \%
\end{aligned}
$$

Since, $\mathrm{BW}>500 \mathrm{MHz}$ and $\mathrm{FBW}_{1 \& 2}>25 \%$. The proposed antenna has wideband properties.

Figure (4) shows the real and the imaginary parts of the impedance versus frequency for the final design. The real and the imaginary parts are showing that the designed antenna has good input impedance at the two resonant frequencies $2.4 \mathrm{GHz}$ and $3.5 \mathrm{GHz}$.

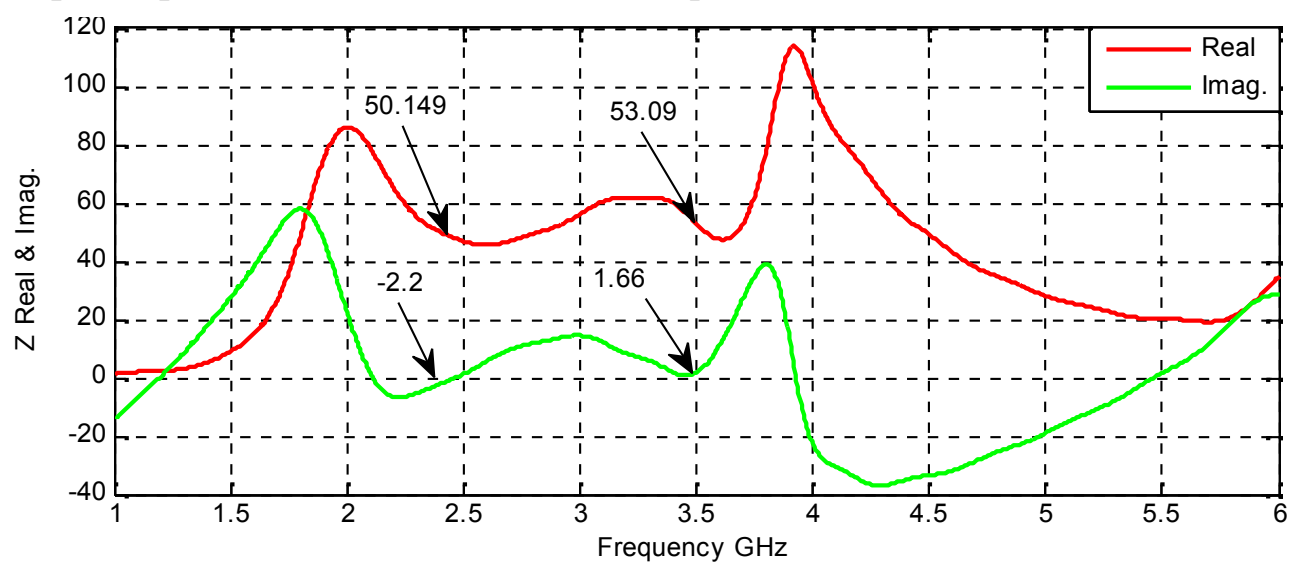

Fig. (4) Impedance versus frequency 
Figure (5) shows that the antenna has maximum value of efficiency at the two resonant frequencies, $\eta=94.75 \%$ at $2.4 \mathrm{GHz}$ and $\eta=93.01 \%$ at $3.5 \mathrm{GHz}$. High efficiency means that the designed antenna radiates the most power that delivered by the microwave source.

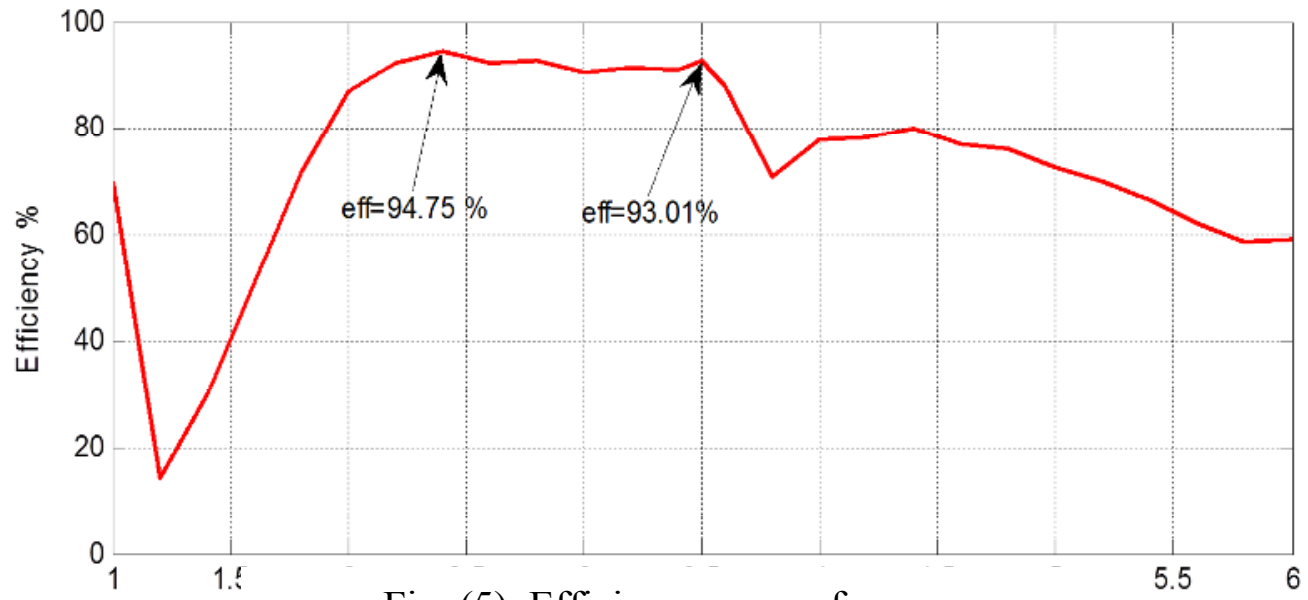

Fig. (5) Efficiency versus frequency

Figure (6) shows the antenna gain as a function of frequency. The designed antenna has a simulation gain of $2.6 \mathrm{dBi}$ at $2.4 \mathrm{GHz}$ and $3.1 \mathrm{dBi}$ at $3.5 \mathrm{GHz}$.

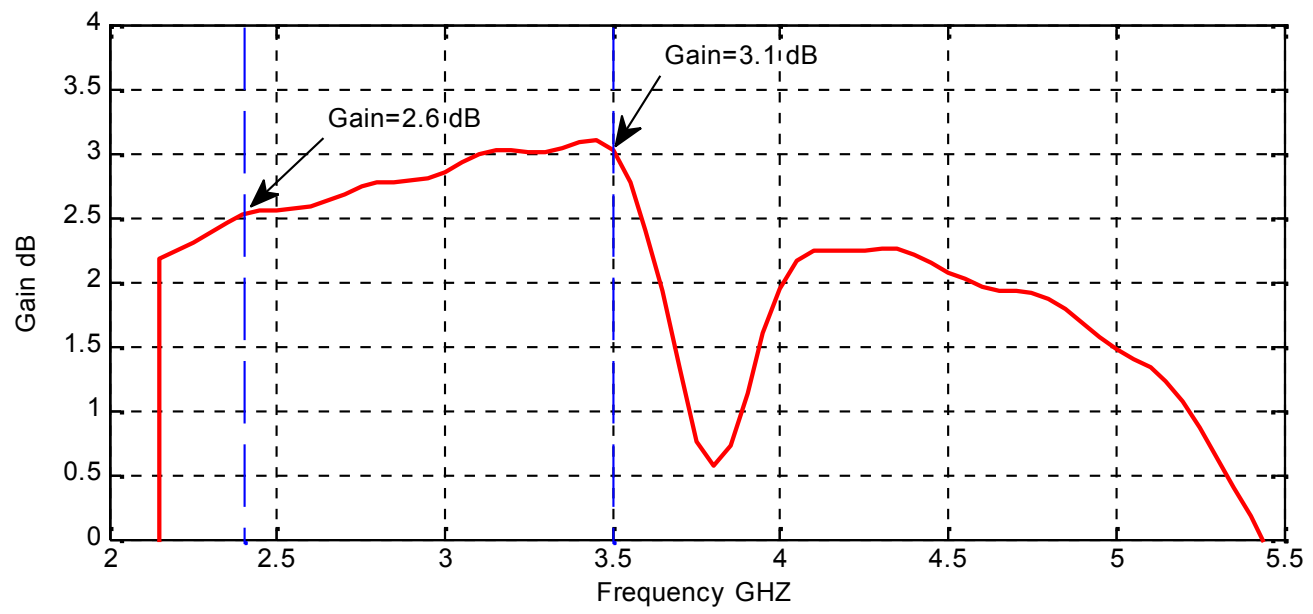

Fig. (6) Gain versus frequency

\section{4- MEASUREMENT RESULTS}

All the measurements are carried out at university of Mosul/college of Engineering/Electrical engineering department. The antenna was printed in the solid state laboratory, and the measurements were taken in an echoic chamber, see figure 7. 

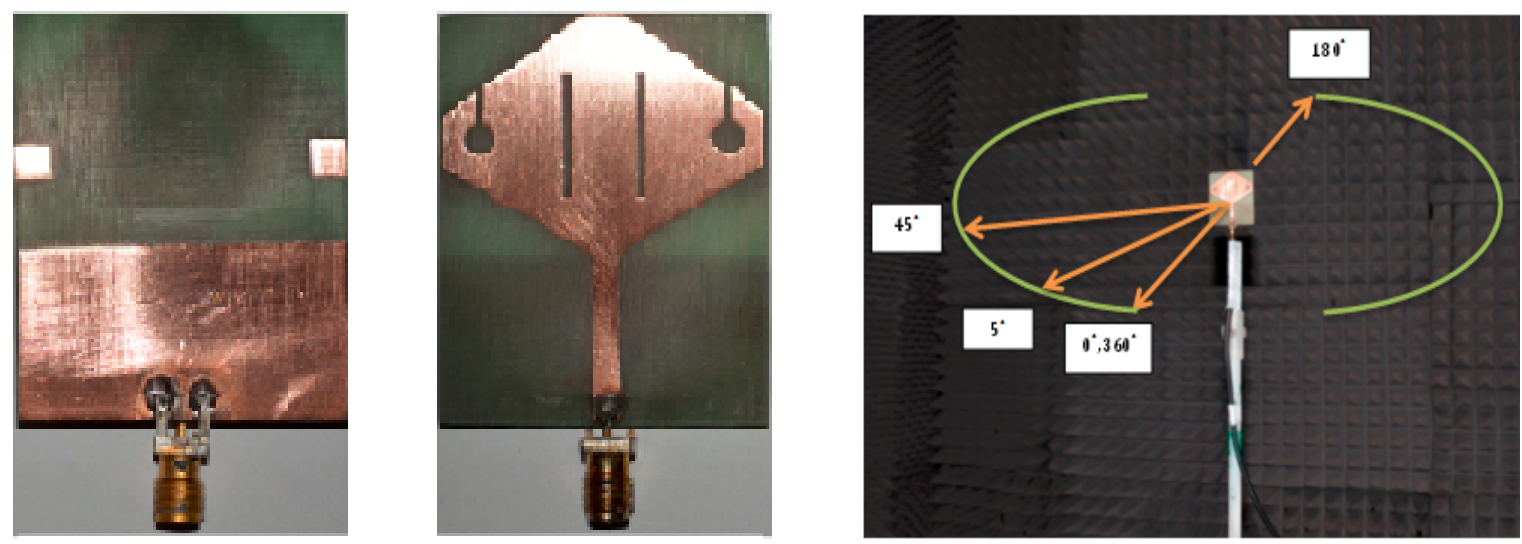

(a)

(b)

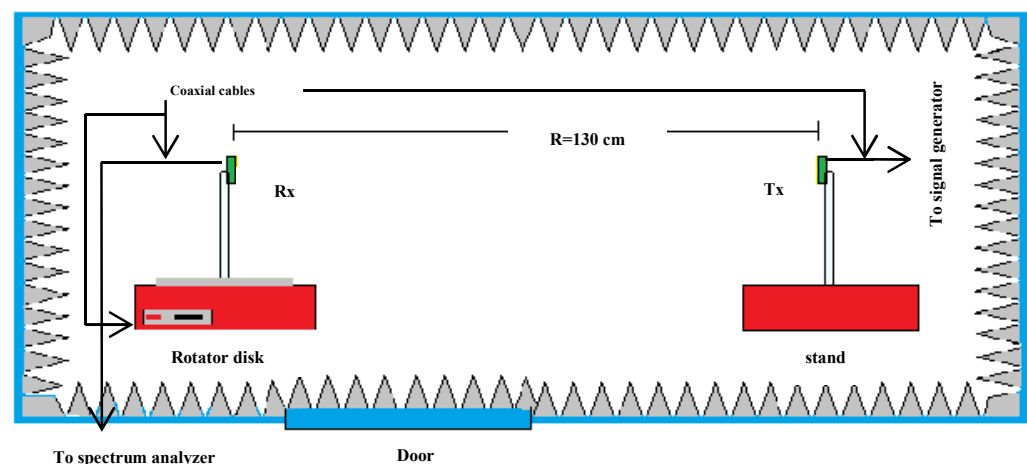

(c)

(a). Printed antenna (b). Antenna in an anechoic chamber

(c). Diagram for the Tx. \& Rx antenna in the chamber Fig. (7) Practical antenna through measurement

Firstly adjust the far filed condition between $\mathbf{T x}$ and $\mathbf{R x}$ in the chamber, and then adjust the antennas direction in order to get maximum radiation intensity.

\section{Radiation pattern}

Figure. (8-a) shows the simulated and measured radiation patterns for both $\mathrm{E}$ and $\mathrm{H}$ planes at $2.4 \mathrm{GHz}$. The measured results are obtained by rotating the receiver in $360^{\circ}$ by step of $5^{\circ}$. Fig. (8-b) shows the simulated results for both $\mathrm{E}$ and $\mathrm{H}$ plane at $3.5 \mathrm{GHz}$. 


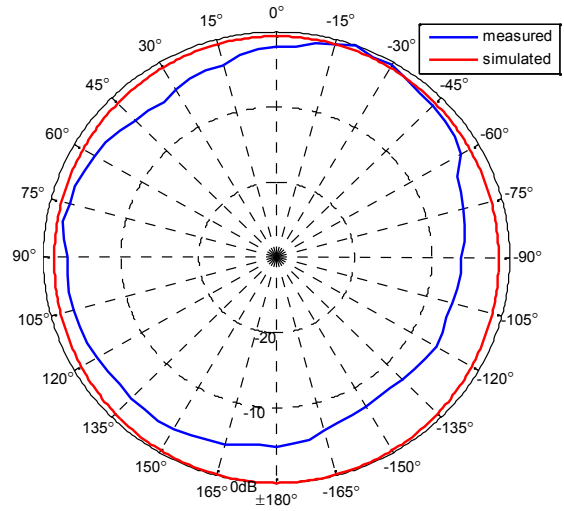

E- plane $2.4 \mathrm{GHz}$

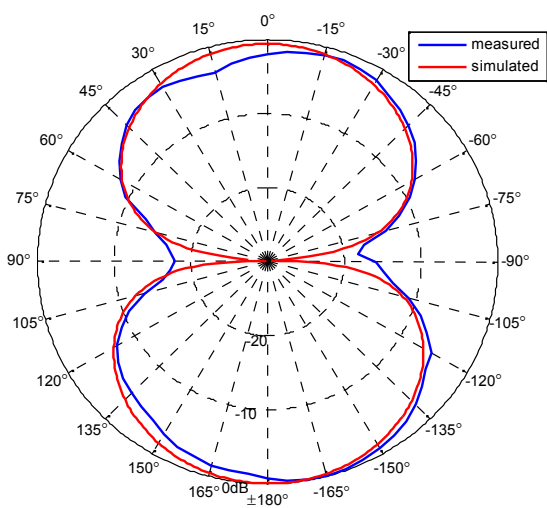

$\mathrm{H}$ - plane $2.4 \mathrm{GHz}$

(8-a) Simulated and measured results at $2.4 \mathrm{GHz}$

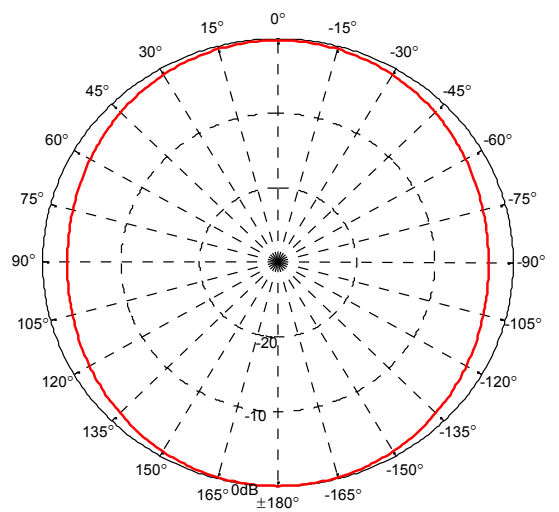

E- plane $3.5 \mathrm{GHz}$

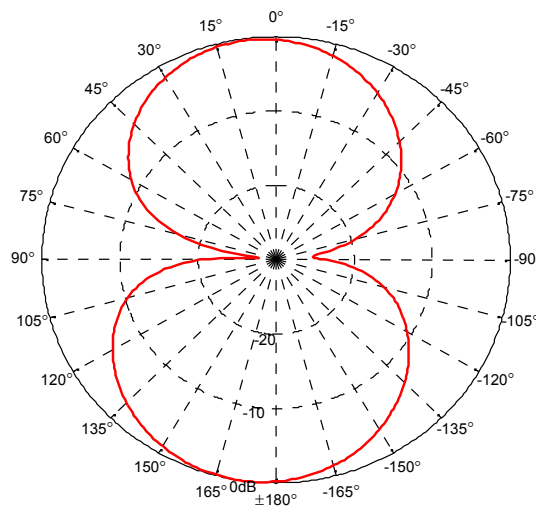

H- plane $3.5 \mathrm{GHz}$

(8-b) Simulated results at $3.5 \mathrm{GHz}$

\section{Gain}

Gain of the designed antenna was calculated by Friis equation.

Where:

$$
\begin{array}{r}
\mathrm{P}_{\mathrm{r}}(\mathrm{dBm})=\mathrm{P}_{\mathrm{t}}(\mathrm{dBm})+\mathrm{G}_{\mathrm{t}}(\mathrm{dB})+\mathrm{G}_{\mathrm{r}}(\mathrm{dB})-F S L \\
F S L(\mathrm{~dB})=20 \log _{10}\left(\frac{4 \pi R}{\lambda}\right) \quad \ldots \ldots \ldots
\end{array}
$$

$\mathrm{P}_{\mathrm{r}} \quad$ Received power.

$\mathrm{G}_{\mathrm{t}} \quad$ Transmitter gain.

FSL Free space loss.
$P_{t} \quad$ Transmitted power.

$\mathrm{G}_{\mathrm{r}} \quad$ Receiver gain.

$P_{t}$ and $P_{r}$ are measured practically in an echoic chamber using the power spectrum analyzer device. Identical antennas were used at transmitter and receiver terminals $\left(\mathrm{G}_{\mathrm{t}}=\mathrm{G}_{\mathrm{r}}\right)$ then apply equations (1) and (2). The practical relative gain is $3.9625 \mathrm{~dB}$ 
Table. 3 shows comparison between the results of our antenna design and the results of other antenna designs.

Table .3 shows comparison between the results

\begin{tabular}{|l|c|c|c|c|c|}
\hline \multicolumn{1}{|c|}{ Paper } & $\begin{array}{c}\text { Dimensions } \\
\mathrm{L} \times \mathrm{W} \times \mathrm{h} \text { in }(\mathrm{mm})\end{array}$ & $\begin{array}{c}\text { Bandwidth } \\
\text { in }(\mathrm{GHz})\end{array}$ & $\begin{array}{c}\text { Return loss } \\
\text { in }(\mathrm{dB})\end{array}$ & $\begin{array}{c}\text { Gain } \\
\text { in }(\mathrm{dBi})\end{array}$ & $\begin{array}{c}\text { Maximum } \\
\text { efficiency }\end{array}$ \\
\hline Our paper & $50 \times 40 \times 1.6$ & 1.786 & -30.8 to -32 & 2.8 to 3.3 & $94.75 \%$ \\
\hline Paper [2] & $54 \times 37.4 \times 1.6$ & 2.2 & -25.0 to -30 & 2.5 & $\ldots \ldots$. \\
\hline Paper [3] & $40 \times 60 \times 1.6$ & 1.345 & -32.0 to -43 & $\ldots \ldots$. & $95.00 \%$ \\
\hline Paper [4] & $51.88 \times 41.36 \times 1.6$ & 1.8 & -33.0 to -37 & 5 & $99.89 \%$ \\
\hline Paper [5] & $35.51 \times 43.16 \times 1.6$ & 1.326 & -13.0 to -21 & 4 & $95.00 \%$ \\
\hline Paper [6] & $45.75 \times 46.2 \times 1.6$ & 0.170 & -24 & 2.64 & $\ldots \ldots$. \\
\hline
\end{tabular}

\section{5- CONCLUSION}

In this paper, a new design rhombic-patch microstrip antenna of broadband suitable for WLAN/WiMAX applications is presented. The patch and ground plane of the antenna are printed onto a (PCB) card with an overall size of $50 \mathrm{~mm} \times 40 \mathrm{~mm} \times 1.6 \mathrm{~mm}$. The antenna has been designed to reduce the ground plane effects by cutting a notch from the patch.

The modest bandwidth of the conventional rectangular patch has been enhanced to wide band of $1.768 \mathrm{GHz}$ using triangle notch at each corner of the radiator. The ground-plane effect on impedance performance is greatly reduced by cutting the notch from the radiator because the electric currents on the ground plane are significantly suppressed at the lower resonant frequencies. In particular, the reduced ground plane makes the antenna structure compact and so it can be easily integrated with the packaging device.

Slots onto the radiator are used to generate the upper resonant frequency. Two square parasitic elements are printed onto the bottom surface of the substrate, dimensions and location of the parasitic elements are controlled on the operating frequencies $2.4 \mathrm{GHz}$ and 3.5 $\mathrm{GHz}$ within acceptable range.

\section{REFERENCES}

[1] C. R. Byrareddy, N. C. Easwar Reddy, and C. S. Sridhar, "Compact dual band planar RMSA for WLAN/WIMAX applications", International Journal of Advances in Engineering \& Technology, Vol. 2, Issue 1, pp. 98-104 Jan 2012.

[2] C. Y. Pan, J. Y. Jan and L. C. Wang, "Compact and Broadband Microstrip-Line-Fed Modified Rhombus Slot Antenna”, Radio Engineering, Vol. 22, No. 3, September 2013.

[3] A. K. Rawat, V. K. Singh and S. Ayub, "A compact wide band microstrip antenna for GPS/WLAN/WiMAX applications". International journal emerging trends in engineering and development, Issue 2, Vol. 7, 2012.

[4] S. Kumar, N. S. Beniwal, and D. K. Srivastava, "Bandwidth enhancement by slot loaded patch antenna for GPS/WLAN/WiMAX applications", International journal of advanced research in computer and communication engineering, Vol. 3, Issue 1, January 2014. 
[5] S. Srivastava and V. K. Singh, "Bow-Tie shaped printed antenna for UMTS/WLAN/WiMAX applications". JECET, Vol. 3, No.1, pp. 0261-0268, February 2014.

[6] Y. E. M. Ali and F. H. A. Hussein, "Design and implementation of a compact rectangular microstrip antenna of enhanced bandwidth" mater thesis, University of Mosul, College of Engineering, 2010.

[7] C.R. Byrareddy, N.C. Easwar, and C.S. Sridhar, "Compact triple band rectangular microstrip antenna for WLAN/WIMAX applications", Journal of Theoretical and Applied Information Technology, Vol. 32 No. 2, October 2011.

[8] D. M. Pozar, "Microwave Engineering", Second Edition, Wiley, New York 1998.

[9] C. A. Balanis: "Antenna Theory Analysis and Design," 3'rd edition, John Wiley and Sons, 2005.

[10] C. C. Chong, F. Watanabe, and H. Inamura, "Potential of UWB Technology for the Next Generation Wireless Communications", IEEE Ninth International Symposium on Spread Spectrum Techniques and Applications, 2006. 